\title{
Elektronisk pasientjournal: Filene og fortroligheten
}

\author{
Georg Apenes \\ Datatilsynet, Postboks 8177 Dep, 0034 Oslo
}

\begin{abstract}
Stadig oftere blir vi tvunget til å betrakte teknologiens Janus-ansikt: De gode hensikter og de spektakulære mulighetene vil alltid ha sine advokater. Ansiktets supplerende profil - teknologiens mer problematiske konsekvenser - er dårligere organisert. Og finansiert. Og institusjonalisert. I løpet av inneværende ti-år vil elektroniske pasientjournaler, knyttet til et sentralt register, være operativt i Norge. Fordelene er iøynefallende; ulempene kanskje noe mer konturfattige. Å finne et balansepunkt er både forvaltningens og politikernes ønske. Og ambisjon. Lykkes det, vil det bli mulig å beholde tillit som en grunnakkord i norsk helsevesen - tillit i trekanten der myndigheter, terapeuter og klienter danner sidene. De følgende refleksjoner er ment som et bidrag til sindig og kjølig ettertanke bl.a. med referanse til aktuelle synspunkter som gjør seg gjeldende innenfor en bredere, europeisk personvern-tankegang. Avslutningsvis stilles dessuten det fundamentale spørsmålet som det blir stadig vanskeligere å avvise: Er egentlig det 21 de århundredes europeer så veldig opptatt av å verne om sitt privatliv; sine personopplysninger ......?
\end{abstract}

Et vittig hode skal engang ha sagt at en pasient er en som slår følge med et symptom til legen.

Som mine lesere selvfølgelig vet, er dette en grovmasket usannhet, men som tilfellet ofte er med en drøy spøk, så kan man finne strimer av tankevekkende sannhet i den. I dette tilfelle rettes oppmerksomhet mot den omstendighet at interessen for én sektor stjeler oppmerksomhet fra en helhet som vitterlig er satt sammen av mange sektorer - for eksempel den som inneholder ønsker om å skjerme sitt private doméne under oppholdet på et sykehus i den hensikt å få reparert sin fot eller sin lever ...... Tankene går til det helhetlige menneskesynet som blant annet kom til uttrykk i Den Hippokratiske legeed der det het:

"Alt det som jeg ser og horer når jeg behandler pasientene eller også utenfor behandlingen, slikt som man ikke skal plapre om, det vil jeg holde for meg selv og anse alt slikt som usagt."

Norske pasienter har fått mer og mer å si. Mer makt. Og paragrafer. Men hva de liker å benytte makten til, kan vanskelig entydig besvares. Vår selvbevissthet er stor og voksende. Når man leser om virksomheten $\mathrm{i}$ Norsk Pasientskadeerstatning og alle klagene og alle utbetalingene av plaster på sårene, skulle man tro at norsk helsepersonale stort sett var travelt opptatt med å gjøre feil - fra diagnose til behandling og videre til oppfølging.

Og kravene om oppreisning og erstatning strømmer inn - godt fulgt opp av medieoppslag ofte utvirket av snedige advokater som representerer klienter som, ifølge dem, har vært utsatt for feilmedisinering, tortur, inkompetanse, kameraderi, forglemmelser og dårlig ledelse. Til og med ren uflaks er blitt erstatningsbetingende.

Pasientene har fått flere og større rettigheter gitt dem av Stortinget de senere årene, og det til Legefore- ningens store tilfredshet. Dette skyldes ikke minst at pasientene, i prinsippet, dermed kan få et medansvar. Både moralsk og juridisk. Kari og Ola skal tas på alvor, de skal gi sine informerte samtykker. Og går det galt, så skal de oftere kunne takke seg selv for det......

Onkel Doktor har fått en medskyldig, og er selvsagt glad for det.

Når klagene strømmer inn og stadig oftere later til å møte sympati og medhold - både $\mathrm{i}$ forvaltningen og $\mathrm{i}$ rettsvesenet, kan det skyldes at pasientene er ute av stand til å overskue konsekvensene av de valg hun eller han tilbys å ta:

Forleden hadde jeg en av mine regelmessige samtaler med min ortoped. Samtaleemnet er mine knær, som, etter å ha medvirket aktivt til mine forflytninger gjennom et par menneskealdre, nå bærer preg av slitasje.

Legen erklærte, at etter de ferskeste røntgenfotografiene å dømme, var jeg fullt kvalifisert til å få gjennomført en operasjon. Her eller der etter min egen preferanse; etter mitt eget forgodtbefinnende.

- Men om du vil få satt inn et nytt kneledd eller ikke får du selv bestemme, sa den statsautoriserte kyndighet.

Jeg anførte der og da, i et vennlig tonefall, at når jeg hadde oppsøkt ham, så var det ut fra den underliggende forutsetning at han nok ville være en bedre beslutningsfatter enn jeg selv ville kunne være. Men nei: Jeg hadde hånden på rattet; jeg fikk ta ansvaret for styringen.

For ikke så veldig mange år siden, var det jeg visste om meg selv og det legen min og hennes medarbeidere visste om meg, omtrent overlappende. Beslutningene ble vennlig, men patriarkalsk, fattet av legen som imidlertid ofte kunne dele sin diagnostiske viten og sine terapeutiske teorier med sin pasient - i kåserende form. 
I 2007 er det mange flere som deltar både i den diagnostiske og $\mathrm{i}$ den påfølgende terapeutiske fasen av et sykdomsforløp. Det anses oppbyggelig nødvendig, og dermed blir spørsmålet om det også er ønskelig mindre interessant.

Når pasientjournaler ikke skal betraktes som allmenninger, har det flere grunner - som alle vektlegges nokså unisont:

- Vi tror at det er en viktig forutsetning for gode behandlingsresultater,

- vi tror helseopplysninger, som hovedregel, knytter seg til følelsesliv og opplevelse av egenverd som begge er beskyttelseverdige goder som det er nødvendig å hegne om med takt og diskresjon, og

- de færreste har tilstrekkelige kunnskaper eller fantasi nok til å overskue når, hvor og hvem der ute som kan tenkes å ville fatte interesse for mine binyrer eller mine utslett.

På den annen side vet vi, av erfaring, at å kunne videreformidle pasientopplysninger dels kan være en forutsetning for å kunne finne individuell hjelp og presise løsninger. Dessuten vil opplysningene ofte være råstoff for forskning som ikke bare kan resultere $i$ hjelp for en plaget gruppe, men bidra til å forebygge eller hjelpe fremtidens pasienter med den samme plagen.

Der står vi så i dag: Vi skal veie den enkelte pasientens antatte behov for hemmelighold med fellesskapets behov for å forske, planlegge og kanskje forutsi generelle utviklingstrekk.

Personverntanker har påvirket og bekreftet helseetikken slik den er nedfelt i lover og forskrifter, men også i profesjonsetikk, tradisjoner og hva vi i mangel av mer presise uttrykk kaller for 'vår kultur' der forstillingen om den svakes moralske særstilling og særkrav fortsatt står sterkt. Og pasienten er per definisjon 'svak'.

Pasienten har fortsatt 'hånden på rattet'. Hennes rettigheter kan ikke uten videre neglisjeres eller suspenderes. Men den teknologiske utviklingen utfordrer både utgangspunkt og hovedregel - særlig informasjonsteknologien. Det kan bli både dyrt, risikabelt og irriterende stadig å skulle spørre pasienten om tillatelse etter først å ha slitt seg møysommelig igjennom en krevende informasjonsprosess som stadig er en betingelse for at det normalt påfølgende samtykke skal oppnå status som 'frivillig og informert'.

Det gjør ikke saken enklere for oss at utlevering av helsedata og samtykket til at de viderebringes $\mathrm{i}$ sin nominative form, stadig oftere vil måtte innebære en parallell utlevering av personopplysninger knyttet til pasientens biologiske linje. Genomets koder gjør helseopplysninger potente på en ganske annen, dramatisk måte $\mathrm{i}$ dag og $\mathrm{i}$ fremtiden enn $\mathrm{i}$ går og $\mathrm{i}$ fortiden selv om arv har vært medisinsk interessant og relevant siden antikken.

Presset og tempoet i utviklingen av den medisinske informatikk kommer fra flere kanter enn pasienten $\mathrm{i}$ hospitalsengen:
- Politikerne maser om effektivisering og øket helseproduksjon. (Eller 'Flere kroner pr. helse' som Jarle Ofstad ironisk traverserer slagordet.)

- Legene er ambisiøse og vil ha kortest veg til flest mulig kunnskaper som kan gi merittering og avansement, og

- den internasjonale, medisinske industri, med den farmaseutiske i spissen, ser sin interesse for ekspansjon og økende markedsvolumer og avkastning best tjent med at ting skjer raskt.

Og samtlige små og store aktører har den beste allierte man overhodet kan tenke seg, nemlig: Din og min grunnleggende interesse av ikke å bli syk - eventuelt av å bli frisk igjen.

Ved hvert nytt, teknologisk skritt fremover er det blitt nødvendig å inngå kompromisser med hensyn til 'hånden på rattet'. Skjermingen, det informerte samtykket og begrensningen av pasientinformasjon til personer, funksjoner eller grupper som har et avklaret, legitimt behov for å vite, blir vanskeligere og vanskeligere. Velmente og ofte godt gjennomtenkte regimeregler er gjerne på plass når de medisinsk-administrative systemene setter seg i bevegelse. Prinsippet om at det skal sondres mellom 'need to know' og 'nice to know' slik vi kjenner det fra det klassiske personvernet er det svært sjelden åpen diskusjon om.

$\mathrm{Vi}$ vet om de gamle papirjournalene i institusjonene at opp mot 20 prosent av dem til enhver tid ikke befant seg der de skulle være - for eksempel i arkivet. Så kom de elektroniske journalene. Det gode med dem er at de ikke forsvinner eller rotes bort så lett. De er som oftest bare et tastetrykk eller fem-seks- unna. Og de fleste skjønner hvor verdifullt det vil kunne være å ha pasientens historikk og status så å si på fingertuppene? Men: En journal som blir borte, vil det kunne bli lett etter - en elektronisk journal på vidvanke blir det vanskelig å finne ut hvor har vært - og hva den har gjort der. Eller om noen i mellomtiden har 'fikset' litt på den.

Pasientens eget krav om journalinnsyn vil det være litt enklere å imøtekomme om den kan presenteres på papir enn om det er en sofistikert fil som legges ut på en 'lap-top'?

Jeg er ikke kjent med hvorvidt det foreligger omfattende og kvalitetssikrede undersøkelser av norske borgeres bruk av sine pasientrettigheter med særlig hensyn på samtykkeinstituttet og styringsretten. Jeg vil tro at en slik forskning antagelig vil vise at det $\mathrm{i}$ den somatiske hverdag ikke dreier seg om et plagsomt omfang. Det er da heller ikke avgjørende for en diskusjon av spørsmålet om styringsretten bør modifiseres eller suppleres av andre rettsikkerhetsgarantier. Jeg tror imidlertid at vissheten om eksisterende pasientrettigheter i seg selv bidrar avgjørende til den tillitsakkord mellom helsevesenets medarbeidere og institusjoner på den ene siden og den enkelte borger på den annen, som vi betrakter som et nødvendig gode.

Men forskere, deler av forvaltningen og mange 
politikere hadde vel gjerne sett at pasientrettighetene hadde blitt noe smalere definert og praktisert. Det er også i Europeisk sammenheng nødvendig å konstatere at personvernet opplever en tidvis nokså intens pågang av veltalende reformatorer som vil revidere pasientrettene - særlig under henvisning til et oppgitt behov for et mer strømlinjeformet, økonomieffektivt helsevesen. Da blir gjerne personvernet plassert foran sparekniven og annet, skremmende verktøy. Men hvor bør balansepunktet ligge mellom pasientens interesser og samfunnets/helseindustriens/forskningens?

Noen grei og entydig formel, egnet for hele dette området fra Malta til Finland, kan neppe finnes eller påvises. Men rammer og yttergrenser burde det la det seg gjøre å formulere.

Dette er bakgrunnen for at den såkalte 'Artikkel 29'-gruppen som består av samtlige ledere for datatilsynsmyndighetene innenfor EU-området pluss EØSlandene Liechtenstein, Island og Norge, i januar 2007, enstemmig, vedtok en uttalelse om bruk og behandling av personopplysninger $\mathrm{i}$ forbindelse med innføringen og bruken av elektroniske pasientjournaler. Når helseministeren, som varslet av henne selv i Stortinget, innfører en 'nasjonal helsejournal' vil disse synspunktene representere en autoritet norske lovgivere ikke kan abstrahere seg fra fordi de er konkretiseringer av personverndirektivet fra 1995 som i dag også ligger i bunnen av den norske Lov om behandling av personopplysninger. Hensikten med EPJ-reformen er

- å høyne kvaliteten på behandlingen på grunnlag av bedret pasientinformasjon,

- øke kostnadseffektiviteten og dermed holde helsebudsjettene nede, og

- fremskaffe nødvendige data for å kunne kvalitetskontrollere behandling, utarbeide pålitelig statistikk og gi bedre grunnlag for planlegging innen helsesektoren.

Ved siden av det generelle kravet om innføring av effektive kontrollmekanismer, identifiserer 29-gruppen 10 punkter som alle er ment å bidra til å fastholde pasienten som den sentrale aktør - den omgivelsene er forpliktet til å ta avgjørende hensyn til i en gitt avveiningssituasjon av interesser.

Som første og viktigste prinsipp fastslår 29gruppen retten til selvbestemmelse. Og selv om opprettelsen av et elektronisk, sentralisert helseregister ikke bygger på informert og frivillig tilslutning fra hver enkelt borger, så skal hennes og hans meninger om hvorledes medisinske data om dem skal benyttes spille en viktig rolle som sikkerhetsforanstaltning. Pasienten skal - i prinsippet - kunne hindre at opplysninger om henne eller ham, innsamlet av en behandler utleveres til andre helsearbeidere dersom vedkommende pasient selv ønsker det slik.

Det forutsettes videre i uttalelsen at ingen skal kunne tvinges til å være med i det nasjonale registret mot eget ønske, og at det, når lovgiveren har besluttet innføring, også skal anvises hvorledes det skal gås frem dersom noen måtte ønske å trekke seg ut av det.

Det er imidlertid ett parameter som ikke er gjenstand for særlig meget oppmerksomhet, verken i Brussel eller i vår hjemlige debatt, og det er pasientens egen oppfatning av pasienten. Eller, sagt på en annen måte: Gjenspeiler dagens juridisk og politiske forankrede vilje til å la pasientene beholde sine grep på rattene, pasientenes egne prerogativer? Og er de sementert og uten målbare tendenser til endringer?

Jeg er selv ikke så aldeles sikker og mener vi ved anledninger som dette bør være villige til å granske hvorvidt idealene samsvarer med virkeligheten. Min tvil får særlig næring av utviklingen i moderne massemedia der grenser flyttes - så å si daglig - til de manges øredøvende begeistring når tabuer forsvinner og intimsfærer legges ut til offentlig park. Og rett betenkt er det vel vi kjøpere og lesere som går foran og viser vei med vårt pirrebehov mens redaktørene og journalistene bare følger etter?

Særlig forekommer det meg at veggene i intimsfæren begynner å bli temmelig gisne og at temaer som i går var 'hysj-hysj' i dag nærmest er trivialiserte. Hvordan kan vi vente at dagens unge skal betrakte svangerskapsavbrudd som særlig sensitive personopplysninger når angrepiller deles ut på nachspiel?

Og: Etter hvert som de fleste høye og halvhøye samfunnstopper beretter utførlig offentlig om sine nervesammenbrudd, så blir de psykiatriske lidelsene antagelig mindre eksotiske og mindre sensitive?

Særlig forekommer det meg at dersom det blir enda mer vanlig å betrakte trygghet som en rimelig gevinst når egen integritet og privatsfære er innsatsmidlene, ja da kan både helsevesenet og den medisinske forskningen se meget lyst på fremtiden ......?

For dersom pasienten selv ikke vil beholde hånden på rattet kan verken forskningsetiske komiteer, Stortinget eller Datatilsynet teipe den fast? 